\title{
Effects of replacing marine fishmeal with graded levels of Tra Catfish by-product protein hydrolysate on the performance and meat quality of pigs
}

\author{
N.T. Thuy ${ }^{1 \#}$, M. Joseph ${ }^{2}$ \& N.C. Ha ${ }^{3}$ \\ ${ }^{1}$ Department of Animal Science, College of Agriculture and Applied Biology, CanTho University, Campus II, 3/2 Street, \\ Ninh Kieu District, CanTho City, Viet Nam \\ ${ }^{2}$ Department of Animal Science, University College of Agriculture and Environmental Studies, P. O. Box 27, Bunso, \\ Eastern Region, Ghana \\ ${ }^{3}$ Department of Food Technology, College of Agriculture and Applied Biology, CanTho University, Campus II, 3/2 Street, \\ Ninh Kieu District, CanTho City, Viet Nam
}

(Received 5 October 2015; Accepted 15 March 2016; First published online 25 July 2016)

Copyright resides with the authors in terms of the Creative Commons Attribution 2.5 South African Licence.

See: http://creativecommons.org/licenses/by/2.5/za

Condition of use: The user may copy, distribute, transmit and adapt the work, but must recognise the authors and the South African Journal of Animal Science.

\begin{abstract}
A feeding trial was carried out to evaluate the effects of replacing fish meal (FM) with Tra Catfish (Pangasius hypophthalmus) by-product protein hydrolysate (TPH) on performance and carcass quality in pigs. Forty crossbred castrated (Yorkshire $x$ Landrace) male pigs with an initial average bodyweight of $22.8 \pm$ $1.5 \mathrm{~kg}$ were allocated to 40 individual pens in a randomized complete block design with eight replications. The pigs were fed a control diet (TPHO) with FM as sole protein supplement. In the experimental diets, $100 \%$ (TPH100), 75\% (TPH75), 50\% (TPH50) and 25\% (TPH25) of the crude protein (CP) from FM was replaced by the $\mathrm{CP}$ from $\mathrm{TPH}$. The results showed no significant differences in average daily feed intake (ADFI) in all treatments during the growing and finishing phases. However, daily weight gain (ADG) was higher in TPH75 (655 g/day) and TPH100 (663 g/day) than in TPHO (639 g/day). Feed conversion ratio (FCR) was improved with higher inclusion of TPH in the diets. Carcass yield and dressing percentage were not affected by treatments, but abdominal fat and backfat thickness were higher and in the loin-eye area lower in TPH100 compared with TPHO. Polyunsaturated fatty acids (PUFA), ether extract (EE) contents and meat colour values $\mathrm{a}^{*}$ (redness) in the longissimus dorsi muscle increased with TPH replacement level. Feed costs were $10 \%$ lower in TPH100 compared with TPHO. In conclusion, replacing FM with TPH improved the performance, but resulted in an increase in backfat thickness and fat content of meat. However, because of reduced feed costs, complete replacement of FM would still be profitable for pig producers in Vietnam.
\end{abstract}

Keywords: Backfat thickness, longissimus dorsi muscle, fatty acid, Pangasius hypophthalmus

\#Corresponding author: nthithuycn@ctu.edu.vn

\section{Introduction}

Pangasius hypophthalmus (Vietnamese Tra Catfish) is considered the major fish species of the country, and contributes significantly to socio-economic development through exporting the processed fillet (Minh, 2014). Total production of Tra Catfish in Vietnam reached 1.17 million tons in 2013. Increasing production of catfish implies an increase in its by-products, which account for $62 \%-67 \%$ of whole catfish (Minh, 2014). Traditionally, Tra Catfish by-products, which include head, bone, skin, scrap meat and the abdominal organs, are ground fresh, boiled, the oil extracted, and dried to produce catfish by-product meal in commercial processing companies (Thuy et al., 2011). However, in the process, large volumes of wastewater are discarded, resulting in environmental pollution. This is a wasted protein resource that is not normally used in pig diets. This wastewater by-product can be converted into Tra Catfish by-product protein hydrolysate (TPH) by adding enzyme papain, followed by mixing with solid matter and drying to powder to produce the catfish by-product of protein hydrolysate (TPH). The optimal conditions for protein hydrolysis are presented at a temperature of $55^{\circ} \mathrm{C}$ and $\mathrm{pH} 7.5$ in 240 minutes. The major components after hydrolysis of the by-product are peptides with different molecular weights (Thuy et al., 2015).

However, using TPH in the diets for pigs is still undergoing research. There are no published data on finishing pigs regarding the evaluation of meat quality, although pig production is a dominant and rapidly developing form of livestock production in Vietnam. Pork accounts for about $72.8 \%$ of the total meat consumption of the country (GSO, 2014). Conventional protein supplements for commercial pigs, such as 
marine fish meal (FM) and soybean meal, have become relatively expensive. The resulting imbalance between feed and animal production prices has reduced profitability for pig farmers (Thuy et al., 2011). Hence, a protein source from the by-product of Tra Catfish fillet processing is a valuable alternative for use in pig rations. Therefore, supplementation of feed with powdered TPH may be useful because this component lowers prices competitively in comparison with other commercial feed ingredients. The aim of this study was to improve the quality of diets for pigs by replacing marine FM with graded levels of TPH as a protein source in the diets for growing-finishing pigs and to evaluate the effect on growth performance and meat quality.

\section{Materials and Methods}

A total of 40 crossbred castrated (Yorkshire $x$ Landrace) male pigs of the same age (two months old) with an initial average live weight of $22.8 \pm 1.5 \mathrm{~kg}$ (mean \pm SD) were used in the experiment. The study was arranged as a randomized complete block design with five treatments and eight replicates, with the pen as the experimental unit, and the blocks based on the initial bodyweight. The pigs were housed in 40 individual $60 \mathrm{~cm} \times 150 \mathrm{~cm}$ pens on the experimental farm, each with a feeder and an automatic nipple drinker. The daytime temperature during the experiment ranged from $31^{\circ} \mathrm{C}$ to $35^{\circ} \mathrm{C}$. All pigs were vaccinated against hog cholera and foot-and-mouth disease. The experimental feed was given ad libitum four times per day at 7:00, 11:00, 14:00 and 16:00. Leftovers were collected the following morning before the FM, and leftover samples were stored in a freezer for dry matter (DM) analysis. Data collection was carried out in two phases; growing (22.4 - $60 \mathrm{~kg} \mathrm{BW}$ ) and finishing (60 - $101 \mathrm{~kg} \mathrm{BW).} \mathrm{The} \mathrm{growing} \mathrm{phase} \mathrm{lasted} 66$ days and the finishing period 52 days. The pigs were weighed at the beginning and end of each phase, feed intake was recorded, and then FCR was calculated as feed intake divided by weight gain.

Before the start of the experiment, the DM and chemical composition of feed ingredients were analysed. Five experimental diets for growing and finishing phases were introduced to the pigs, and were formulated to contain $166-167 \mathrm{~g} \mathrm{CP} / \mathrm{kg}$ and $12.8-12.9 \mathrm{MJ} / \mathrm{kg}$ of ME for the growing phase; and $146-147 \mathrm{~g}$ $\mathrm{CP} / \mathrm{kg}$ and $13.3-13.4 \mathrm{MJ} / \mathrm{kg} \mathrm{ME}$ for the finishing phase. The basal ingredients provided $60 \%$ of the $\mathrm{CP}$, with the remainder being supplied from FM and TPH in all diets. Rice bran, broken rice and maize meal were the basal ingredients. The $\mathrm{CP}$ in the basal diet (TPHO) was provided by marine FM alone, and the four experimental diets were formulated with $100 \%, 75 \%, 50 \%$ and $25 \%$ of the CP from FM being replaced by $\mathrm{TPH}$. Fish meal was bought from factories that process small marine fish, and all diets were supplemented with a standard mixture of vitamins and minerals.

The Tra Catfish by-product was obtained from a catfish fillet-processing factory in the industrial zone, Can Tho City, Vietnam, and processed into TPH according to Thuy et al. (2015). Briefly, catfish by-product (head, bone (80\%) and scrap meat (20\%)) was ground, boiled and pressed to obtain the soluble matters. This was then centrifuged and extracted to obtain a protein solution. This protein solution was concentrated to $10 \%$ (the best concentration for protein hydrolysis by enzyme papain). The $\mathrm{pH}$ and temperature were adjusted to the optimal condition $\left(7.5\right.$ and $55^{\circ} \mathrm{C}$, respectively) for hydrolytic process. The ratio of enzyme to protein solution was $1 \mathrm{mg} \mathrm{E}$ papain/ $2.5 \mathrm{~g}$ protein in $10 \mathrm{~mL}$ solution. The time for hydrolysis with this condition was set at 240 minutes and the degree of hydrolysis was achieved around $29.2 \%$ (calculated according to

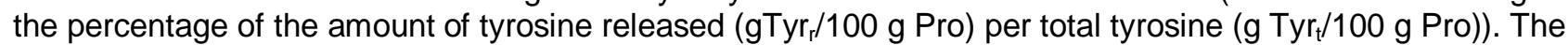
solution was dried with the previous solid matter to produce the final product called TPH. The TPH was mixed each week with the basal ingredients and fed to the pigs.

At the end of the finishing phase, the pigs were weighed (final weight) before being transported to a local abattoir over four days (10 pigs/day), where carcass data were collected. The hot carcass weight was the weight after slaughter, excluding blood, hair, visceral organs and gastrointestinal tract. Dressed weight was evaluated as the hot carcass weight minus the head, lower legs, tail and abdominal fat, and the dressing percentage was calculated. All the parameters were measured on the left side of each carcass. Backfat thickness was measured at the height of the 1st rib, last rib and last lumber vertebra, using a ruler, and at the 10th rib, Three quarters of the lateral length of the longissimus dorsi (LD) muscle perpendicular to the outer skin surface and the average back fat thickness were calculated. The loin eye area was measured by delimiting the contour of the LD muscle, wrapped in plastic, with a special pen, and calculating the area using a planimeter. Fresh loin muscle samples were taken at the 10th rib for $\mathrm{pH}$ measurement, chemical analysis of DM, CP, ether extract (EE), fatty acid content and colour value.

The chemical composition of feed ingredients, diets, feed refusals and meat was determined using the following standard AOAC methods (AOAC, 2000). Crude protein was determined by the Kjeldahl method. Total ash was the residue after burning the sample at $550^{\circ} \mathrm{C}$ and organic matter (OM) was calculated by difference. Ether extract was determined by Soxhlet extraction. The $\mathrm{pH}$ of the LD muscle was measured at $24 \mathrm{~h}$ after slaughter using a digital $\mathrm{pH}$ meter. The fatty acid composition of loin muscle samples was analysed by gas chromatography (GC). To do that, the total lipid content of muscle was isolated and purified using the chloroform-methanol extraction procedure of Folch et al. (1957). The extracted lipids were 
converted to fatty acid methyl ester using $\mathrm{BF}_{3}$ and methanolic $\mathrm{KOH}$, and analysed by $\mathrm{GC}$ (Kenichi \& Yumeto, 2010). For amino acid analysis, the method of Kang-Lyung Woo (2001) was used. To do that, the feed sample was hydrolyzed first with $6 \mathrm{M} \mathrm{HCl}$ containing $0.1 \%$ phenol at $145^{\circ} \mathrm{C}$ for 4 hours to obtain a sample solution. This sample solution was then purified by cation-exchange column $(100 \times 13 \mathrm{~mm}$ I.D. Dowe $\times 5 \times 8$, rate: 6 drops $/ \mathrm{min}$ ), washed with water and eluted amino acids with $40 \mathrm{~mL}$ of $4 \mathrm{M} \mathrm{NH}_{3}$ (rate: 6 drops $/ \mathrm{min}$ ) to obtain the amino acid solution. Derivatization was carried out at $50^{\circ} \mathrm{C}$ for $30 \mathrm{~min}$ for benzylthiocarbamyl (BZTC) derivatives. The RP-HPLC system was used as Spectra-Physics 8800 ternary solvent delivery with Spectra 200 programmable wavelength UV detector at $246 \mathrm{~nm}$. The sensitivities of BZTC derivatives were detected at 0.05 AUFS. The column used was Nova-Pak C18 (300 X 3.9 i.d., $4 \mu \mathrm{m}$ dimethyloctadecylsilylbonded amorphous silica waters). The mobile phase included $A$ solvent as $0.02 \mathrm{M} \mathrm{NaH}_{2} \mathrm{PO}_{4}$ containing $5 \%$ methanol and $1.5 \%$ tetrahydrofuran; B solvent was as A solvent-acetonitrile (50:50); C solvent was as acetonitrile-water $(70: 30)$. The objective meat colour on the LD was evaluated on the 10 th rib surface using a colorimeter (Chromameter Minolta, CR- 200, Japan), and expressed as Hunter $L^{*}, a^{*}, b^{*}$ values of objective colour. The $L^{*}$ reading is a measure of the lightness or darkness of a meat sample; the $a^{*}$ reading of the redness or greenness of the sample (the more positive the number, the redder the sample); the $b^{*}$ reading of yellowness and blueness (the more positive the number, the yellower the sample).

Analysis of variance was performed according to a randomized complete block design, using the general linear model of Minitab Statistical Software Version 15. Treatment means that showed significant differences at $P<0.05$ were compared using Tukey's pair-wise comparison procedure. The statistical model was as follows:

where $Y_{\mathrm{ij}}$ is growth performance or meat quality;

$$
Y_{i j}=\mu+\alpha_{i}+\beta_{j}+e_{i j}
$$

$\mu$ is overall mean averaged over all treatments and all possible blocks;

$\alpha_{i}$ is effect of treatment $i$;

$\beta_{\mathrm{j}}$ is effect of block $\mathrm{j}$;

$\mathrm{e}_{\mathrm{ij}}$ is random error associated with assigned to treatment $\mathrm{i}$ in block $\mathrm{j}$.

Table1 Dry matter (DM), chemical composition and essential amino acids ( $\mathrm{g} / \mathrm{kg} \mathrm{DM}$ ) of diet ingredients

\begin{tabular}{lcccccc}
\hline Chemical composition, (\%) & Broken rice & Rice bran & Maize meal & Soybean & FM & TPH \\
\hline Dry matter & 881 & 850 & 880 & 860 & 856 & 870 \\
Crude protein & 83 & 100 & 91 & 423 & 550 & 510 \\
Ether extract & 6.2 & 85 & 14.8 & 119 & 71.2 & 139 \\
Ash & 37.8 & 89 & 31.2 & 96 & 256 & 231 \\
Crude fibre & 38.0 & 106 & 51.0 & 148 & 21.0 & 21.2 \\
$\quad$ NFE & 834 & 620 & 812 & 211 & 102 & 98.8 \\
Essential amino acids (g/kg DM) & & & & & & \\
Lysine & 3.59 & 4.01 & 3.52 & 24.0 & 52.5 & 51.8 \\
Methionine & 2.09 & 2.02 & 1.81 & 5.50 & 21.5 & 21.0 \\
Phenylalanine & 2.51 & 3.82 & 4.69 & 17.7 & 18.1 & 14.1 \\
Isoleucine & 3.90 & 5.70 & 3.40 & 15.5 & 19.4 & 13.0 \\
Leucine & 7.10 & 8.20 & 10.4 & 21.1 & 32.4 & 32.4 \\
Histidine & 2.30 & 4.11 & 3.10 & 8.90 & 12.2 & 14.5 \\
Arginine & 7.80 & 10.0 & 4.20 & 18.8 & 25.4 & 29.2 \\
& & & & & & \\
\hline
\end{tabular}

FM: fish meal; TPH: Tra Catfish by-product protein hydrolysate; NFE: nitrogen-free extract.

\section{Results}

The chemical composition, metabolizable energy and amino acids content of the raw materials used to compose the experimental diets are presented in Table 1. The CP, EE, lysine and methionine contents of FM 
(550; $71.2 ; 52.5$ and $21.5 \mathrm{~g} / \mathrm{kg} \mathrm{DM}$, respectively) were different from those of the TPH (510; $139 ; 51.8$ and $21.0 \mathrm{~g} / \mathrm{kg} \mathrm{DM}$, respectively).

Table 2 Composition of pig experimental rations and calculated analysis (\% DM) and amino acid composition (g/kg DM)

\begin{tabular}{|c|c|c|c|c|c|}
\hline \multirow{2}{*}{$\begin{array}{l}\text { Composition } \\
\text { (g/kg DM) }\end{array}$} & \multicolumn{5}{|c|}{$\operatorname{Diet}^{(*)}$} \\
\hline & TPHO & TPH25 & TPH50 & TPH75 & TPH100 \\
\hline \multicolumn{6}{|l|}{ Grower diets (22 - $60 \mathrm{~kg} \mathrm{BW})$} \\
\hline Broken rice & 22.0 & 22.3 & 20.0 & 23.5 & 22.3 \\
\hline Rice bran & 28.3 & 29.8 & 30.0 & 32.0 & 32.0 \\
\hline Maize meal & 32.0 & 30.0 & 31.8 & 26.1 & 27.1 \\
\hline Soybean meal & 5.0 & 5.0 & 5.0 & 5.0 & 5.0 \\
\hline Fish meal & 12.5 & 9.38 & 6.25 & 3.13 & 0 \\
\hline TPH & 0 & 3.40 & 6.74 & 10.1 & 13.5 \\
\hline Vitamin-mineral premix ${ }^{(\star \star)}$ & 0.2 & 0.2 & 0.2 & 0.2 & 0.2 \\
\hline Crude protein & 167 & 167 & 167 & 167 & 166 \\
\hline Ether extract & 36.3 & 40.9 & 44.9 & 48.6 & 51.0 \\
\hline Lysine & 0.97 & 0.98 & 0.99 & 1.01 & 1.02 \\
\hline Methionine & 0.43 & 0.44 & 0.43 & 0.44 & 0.45 \\
\hline Methionine + cystine & 0.64 & 0.65 & 0.65 & 0.65 & 0.66 \\
\hline Threonine & 0.52 & 0.52 & 0.53 & 0.53 & 0.54 \\
\hline Tryptophan & 0.22 & 0.23 & 0.23 & 0.24 & 0.24 \\
\hline $\mathrm{ME}, \mathrm{MJ} / \mathrm{kg}$ feed $\mathrm{DM}$ & 12.8 & 12.8 & 12.8 & 12.8 & 12.9 \\
\hline \multicolumn{6}{|l|}{ Finisher diets (60 - $100 \mathrm{~kg} \mathrm{BW)}$} \\
\hline Broken rice & 30.0 & 27.1 & 27.4 & 28.4 & 26.6 \\
\hline Rice bran & 28.8 & 30.5 & 30.0 & 31.0 & 34.0 \\
\hline Maize meal & 29.0 & 30.0 & 30.0 & 27.7 & 26.3 \\
\hline Fish meal & 12.0 & 9.0 & 6.0 & 3.0 & - \\
\hline TPH & 0 & 3.2 & 6.5 & 9.7 & 13.0 \\
\hline Vitamin-mineral premix ${ }^{(* *)}$ & 0.2 & 0.2 & 0.2 & 0.2 & 0.2 \\
\hline Crude protein & 146 & 146 & 146 & 146 & 147 \\
\hline Ether extract & 38.1 & 41.4 & 43.1 & 45.7 & 50.5 \\
\hline Lysine & 0.96 & 0.96 & 0.97 & 0.98 & 0.99 \\
\hline Methionine & 0.43 & 0.43 & 0.44 & 0.44 & 0.44 \\
\hline Methionine +cystine & 0.56 & 0.55 & 0.56 & 0.57 & 0.57 \\
\hline Threonine & 0.49 & 0.50 & 0.50 & 0.49 & 0.51 \\
\hline Tryptophan & 0.15 & 0.16 & 0.15 & 0.16 & 0.16 \\
\hline $\mathrm{ME}, \mathrm{MJ} / \mathrm{kg}$ feed $\mathrm{DM}$ & 13.3 & 13.3 & 13.4 & 13.4 & 13.4 \\
\hline
\end{tabular}

\footnotetext{
${ }_{(\star)}$ TPHO: $100 \%$ crude protein (CP) from fish meal (FM); TPH25: 75\% CP from FM and 25\% CP from Tra Catfish byproduct protein hydrolysate (TPH); TPH50: 50\% CP from FM and 50\% CP from TPH; TPH75: 25\% CP from FM and 75\% CP from TPH; TPH100: 100\% CP from TPH.

${ }_{(* *)}$ Per kg complete diet: Vitamins: Vit. A $45 \times 10^{5} \mathrm{IU}$; vit. D $45 \times 10^{4} \mathrm{IU}$; vit. E $44 \times 10^{2}$; vit. $\mathrm{K}_{3} 280 \mathrm{mg}$; vit. $\mathrm{B}_{1} 600 \mathrm{mg}$; Vit. $B_{2} 200 \mathrm{mg}$; vit. $B_{6} 320 \mathrm{mg}$; vit. $B_{12} 6 \times 10^{3} \mu$; biotin $10^{4} \mu \mathrm{g}$; folic acid $160 \mathrm{mg}$; nicotinic acid $44 \times 10^{2} \mathrm{mg}$; pantothenic acid $24 \times 10^{2} \mathrm{mg}$.

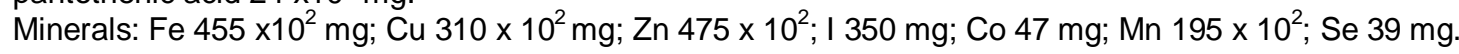


The chemical and amino acid compositions of the experimental diets are shown in Table 2. All experimental diets of grower and finisher had the same contents of CP and calculated ME: $166-167 \mathrm{~g}$ $\mathrm{CP} / \mathrm{kg}$ and $12.8-12.9 \mathrm{MJ} / \mathrm{kg}$ in grower diets; and $146-147 \mathrm{~g} \mathrm{CP} / \mathrm{kg}$ and $13.3-13.4 \mathrm{MJ} / \mathrm{kg}$ in finisher diet.

The effects of TPH on growth performance of pigs are shown in Table 3. There were no significant differences in ADFI in pigs fed all diets of both growing and finishing phases. However, there were significantly higher $(P<0.01)$ final bodyweights in pigs fed TPH75 $(100.2 \mathrm{~kg})$, TPH100 $(101.1 \mathrm{~kg})$ compared with TPH25 $(98.7 \mathrm{~kg})$ and TPHO $(98.4 \mathrm{~kg})$. The highest ADG was recorded in TPH100 (663 g/day) with the lowest in TPHO (639 g/day) in the overall phases. The highest FCR was recorded in TPHO (3.32 $\mathrm{kg}$ feed $\mathrm{DM} / \mathrm{kg}$ gain) and the lowest in TPH100 $(3.18 \mathrm{~kg}$ feed DM/kg gain) $(P<0.05)$. The cost of feed per $\mathrm{kg}$ gain decreased with increasing inclusion of TPH in the diet (TPH25, TPH50, TPH75 and TPH100 was 96.8\%, 95\%, 92.5\% and 90\%, respectively, compared with TPHO).

Table 3 Effects of protein hydrolysate from Tra Catfish by-product on the growth performance of pigs

\begin{tabular}{|c|c|c|c|c|c|c|c|}
\hline \multirow{2}{*}{ Parameters ${ }^{\star *}$} & \multicolumn{6}{|c|}{ Diet $^{*}$} & \multirow{2}{*}{$P$} \\
\hline & TPHO & TPH25 & TPH50 & TPH75 & TPH100 & SEM & \\
\hline \multicolumn{8}{|c|}{ Growing phase (22 - $60 \mathrm{~kg} \mathrm{BW)}$} \\
\hline ADFI (kg DM /day) & 1.60 & 1.60 & 1.60 & 1.60 & 1.61 & 0.02 & 0.81 \\
\hline ADG (g/day) & $551^{c}$ & $566^{\mathrm{b}}$ & $561^{\mathrm{bc}}$ & $574^{\mathrm{ab}}$ & $583^{\mathrm{a}}$ & 3.74 & 0.00 \\
\hline FCR ( $k g$ feed/kg gain) & $2.95^{\mathrm{a}}$ & $2.84^{b}$ & $2.85^{b}$ & $2.79^{\mathrm{b}}$ & $2.75^{b}$ & 0.02 & 0.00 \\
\hline \multicolumn{8}{|c|}{ Finishing phase (60 - $100 \mathrm{~kg} \mathrm{BW})$} \\
\hline ADFI (kg DM /day) & 2.62 & 2.61 & 2.60 & 2.60 & 2.61 & 0.02 & 0.82 \\
\hline ADG (g/day) & $750^{b}$ & $749^{b}$ & $749^{b}$ & $757^{\mathrm{ab}}$ & $764^{\mathrm{a}}$ & 4.02 & 0.03 \\
\hline FCR ( $k g$ feed/kg gain) & 3.50 & 3.48 & 3.47 & 3.40 & 3.41 & 0.03 & 0.22 \\
\hline \multicolumn{8}{|l|}{ Overall (22 - 100 kg BW) } \\
\hline Initial weight (kg/pig) & 23.0 & 22.4 & 23.0 & 23.0 & 22.8 & 0.18 & 0.14 \\
\hline Final weight (kg/pig) & $98.4^{\mathrm{b}}$ & $98.7^{b}$ & $99.0^{\mathrm{b}}$ & $100.2^{\mathrm{a}}$ & $101.1^{\mathrm{a}}$ & 0.24 & 0.00 \\
\hline ADFI (kg DM /day) & 2.12 & 2.11 & 2.10 & 2.10 & 2.11 & 0.02 & 0.80 \\
\hline ADG (g/day) & $639^{c}$ & $647^{\mathrm{bc}}$ & $644^{\mathrm{bc}}$ & $655^{\mathrm{ab}}$ & $663^{\mathrm{a}}$ & 2.70 & 0.00 \\
\hline FCR ( $k g$ feed/kg gain) & $3.32^{\mathrm{a}}$ & $3.26^{\mathrm{ab}}$ & $3.26^{\mathrm{ab}}$ & $3.21^{\mathrm{b}}$ & $3.18^{\mathrm{b}}$ & 0.02 & 0.01 \\
\hline Cost/gain comparison, $\%$ & 100 & 96.8 & 95.0 & 92.5 & 90.0 & & \\
\hline
\end{tabular}

* TPH0: 100\% crude protein (CP) from fish meal (FM); TPH25: 75\% CP from FM and 25\% CP from Tra catfish byproduct protein hydrolysate (TPH); TPH50: 50\% CP from FM and 50\% CP from TPH; TPH75: 25\% CP from FM and 75\% CP from TPH; TPH100: 100\% CP from TPH.

** ADFI: average daily feed intake; ADG: average daily gain; FCR: feed conversion ratio.

${ }^{\mathrm{a}, \mathrm{b}, \mathrm{c}}$ Means within row without a common superscript are significantly different $(P<0.05)$.

The carcass traits, back fat thickness, loin eye area and colour values of the LD muscle are presented in Table 4. There was no significant difference in carcass yield and dressing percentage among diets, but abdominal fat and backfat thickness increased $(P<0.05)$ when pigs were fed higher levels of TPH. The highest abdominal fat was $1.57 \mathrm{~kg}$ (TPH100) and lowest $1.28 \mathrm{~kg}$ (TPH0). The backfat thickness at the 10th rib and average backfat thickness were highest in TPH100 $(2.35 \mathrm{~cm}$ and $2.49 \mathrm{~cm}$, respectively) and lowest in TPHO $\left(2.18 \mathrm{~cm}\right.$ and $2.25 \mathrm{~cm}$, respectively). In contrast, the loin eye area was lowest in TPH100 $\left(43.5 \mathrm{~cm}^{2}\right)$, and highest in TPHO $\left(46.5 \mathrm{~cm}^{2}\right)$. There was no significant difference in moisture, $\mathrm{CP}$, ash contents and $\mathrm{pH}$ value of LD muscle. However, the EE content in the LD muscle of pigs fed TPH25, TPH50, TPH75 and TPH100 (12.13\%, 12.92\%, 12.95\%, 13.04\%, respectively) was higher than in TPH0 (10.89\%). The meat colour values of the LD muscle increased with increasing inclusion of TPH. The $L^{*}$ values increased from 41.8 in TPHO to 52.2 in TPH100. Similarly, the $a^{*}$ value of TPH100 (7.69) was higher than in TPHO (5.26). 
Moreover, the $b *$ values were highest in pigs fed TPH25, TPH75 and TPH100 (1.65) and lowest in pigs fed TPH50 (1.62) and TPHO (1.63).

Table 4 Effects of protein hydrolysate from Tra Catfish by-product on carcass characteristics and pork quality in finishing pigs

\begin{tabular}{|c|c|c|c|c|c|c|c|}
\hline \multirow{2}{*}{ Item } & \multicolumn{6}{|c|}{ Diet $^{1}$} & \multirow{2}{*}{$P$} \\
\hline & TPHO & TPH25 & TPH50 & TPH75 & TPH100 & SEM & \\
\hline \multicolumn{8}{|l|}{ Carcass characteristics } \\
\hline Slaughter weight, kg & 98.9 & 99.0 & 99.5 & 100 & 101 & & \\
\hline Hot carcass weight, $\mathrm{kg}$ & 75.8 & 75.3 & 76.3 & 76.5 & 76.8 & & \\
\hline Carcass yield, \% & 76.6 & 76.0 & 76.6 & 76.5 & 76.1 & 0.31 & 0.08 \\
\hline Dressing percentage, \% & 71.5 & 72.2 & 71.6 & 72.1 & 72.2 & 0.35 & 0.10 \\
\hline Abdominal fat, $\mathrm{kg}$ & $1.28^{\mathrm{a}}$ & $1.30^{\mathrm{a}}$ & $1.35^{\mathrm{ab}}$ & $1.45^{\mathrm{b}}$ & $1.57^{\mathrm{b}}$ & 0.03 & 0.00 \\
\hline \multicolumn{8}{|l|}{ Back fat thickness, $\mathrm{cm}$} \\
\hline At 10th rib & $2.18^{\mathrm{b}}$ & $2.25^{\mathrm{ab}}$ & $2.29^{\mathrm{a}}$ & $2.25^{\mathrm{ab}}$ & $2.35^{\mathrm{a}}$ & 0.02 & 0.00 \\
\hline Average back fat thickness & $2.25^{\mathrm{c}}$ & $2.34^{\mathrm{b}}$ & $2.37^{\mathrm{b}}$ & $2.42^{\mathrm{ab}}$ & $2.49^{\mathrm{a}}$ & 0.02 & 0.00 \\
\hline Loin eye area, $\mathrm{cm}^{2}$ & $46.5^{\mathrm{a}}$ & $46.2^{\mathrm{a}}$ & $45.4^{\mathrm{ab}}$ & $44.2^{\mathrm{bc}}$ & $43.5^{\mathrm{c}}$ & 0.40 & 0.00 \\
\hline \multicolumn{8}{|c|}{ Chemical composition of LD muscle, \% } \\
\hline Moisture & 73.9 & 73.5 & 73.8 & 74.1 & 74.1 & 0.15 & 0.06 \\
\hline Crude protein & 19.9 & 19.9 & 20.0 & 20.4 & 20.4 & 0.18 & 0.11 \\
\hline Ether extract & $10.9^{b}$ & $12.1^{\mathrm{ab}}$ & $12.9^{\mathrm{a}}$ & $12.9^{\mathrm{a}}$ & $13.0^{\mathrm{a}}$ & 0.33 & 0.00 \\
\hline Ash & 1.11 & 1.07 & 1.11 & 1.09 & 1.10 & 0.01 & 0.09 \\
\hline $\mathrm{pH}_{24}$ & 6.41 & 6.32 & 6.22 & 6.38 & 6.32 & 0.83 & 0.46 \\
\hline \multicolumn{8}{|l|}{ Colour of LD muscle } \\
\hline Lightness, L* & $41.8^{\mathrm{b}}$ & $50.9^{a}$ & $51.6^{\mathrm{a}}$ & $52.3^{\mathrm{a}}$ & $52.2^{\mathrm{a}}$ & 0.69 & 0.00 \\
\hline Redness, $\mathrm{a}^{*}$ & $5.26^{\mathrm{b}}$ & $7.33^{\mathrm{a}}$ & $7.43^{\mathrm{a}}$ & $7.68^{\mathrm{a}}$ & $7.69^{\mathrm{a}}$ & 0.19 & 0.00 \\
\hline Yellowness, b* & $1.63^{\mathrm{ab}}$ & $1.65^{\mathrm{a}}$ & $1.62^{\mathrm{b}}$ & $1.65^{\mathrm{a}}$ & $1.65^{\mathrm{a}}$ & 0.01 & 0.00 \\
\hline
\end{tabular}

${ }^{1}$ TPH0: $100 \%$ crude protein (CP) from fish meal (FM); TPH25: 75\% CP from FM and 25\% CP from Tra Catfish byproduct protein hydrolysate (TPH); TPH50: 50\% CP from FM and 50\% CP from TPH; TPH75: 25\% CP from FM and 75\% CP from TPH; TPH100: $100 \%$ CP from TPH.

* L: Black (0) to white (100) scale; a: red (+) to green (-) colour scale; b: yellow (+) to blue (-) colour scale. LD muscle: longissimus dorsi muscle.

${ }_{\mathrm{a}, \mathrm{b}, \mathrm{c}}$ Means within row without a common superscript are significantly different $(P<0.05)$.

The fatty acid composition of the LD muscle is shown in Table 5. There was no significant difference among diets $(P>0.05)$ in monounsaturated fatty acids (MUFA) in the LD muscle. However, polyunsaturated fatty acids (PUFAs) such as linoleic (C18:2, n-6), a-linolenic (C18:3, n-3), C22:5, n-3 (DPA) and C22:6, and n-3 (DHA) increased with higher inclusion of TPH in the diet, with the highest total PUFAs in TPH100 $(19.4 \%)$ and lowest value in TPHO $(18.9 \%)(P<0.05)$.

\section{Discussion}

Protein hydrolysate quality from Tra Catfish by-product varies according to the proportions of the initial by-product composition (scrap meat, skin, head and bone), resulting in a difference in CP content. In this study, the by-product used to produce the TPH constituted mostly head, bone (80\%) and scrap meat (20\%) thus making the CP in the TPH comparatively lower than that from the FM. However, the higher the TPH replacement, the higher EE contents in the diets, which is a result of the higher EE in TPH than that in the FM, which was produced from small, whole marine fish. Recently, several investigations have been conducted on the utilization of Pangasius hypophthalmus by-product to produce TPH by using alcalase enzyme (Minh, 2014) or papain enzyme (Thuy et al., 2015). These researches showed that most of the TPH 
from Tra Catfish by-product undergoes complete hydrolysis, and forms low molecular weight peptide intensity, but high intensity with amino acid mixtures. However, amino acids, particularly lysine and methionine in the TPH, were similar with those from FM.

Table 5 Effect of protein hydrolysate from Tra Catfish by-product on fatty acid composition (\% of total fatty acids) of longissimus dorsi (LD) muscle in finishing pigs

\begin{tabular}{|c|c|c|c|c|c|c|c|}
\hline \multirow{2}{*}{ Fatty acids } & \multicolumn{6}{|c|}{ Diet $^{*}$} & \multirow{2}{*}{$P$} \\
\hline & TPHO & TPH25 & TPH50 & TPH75 & TPH100 & SEM & \\
\hline $\mathrm{C} 12: 0$ & 0.12 & 0.13 & 0.12 & 0.12 & 0.12 & 0.003 & 0.11 \\
\hline C14:0 & 1.66 & 1.69 & 1.66 & 1.67 & 1.65 & 0.016 & 0.44 \\
\hline C16:0 & $29.2^{\mathrm{b}}$ & $28.7^{\mathrm{b}}$ & $29.9^{\mathrm{a}}$ & $29.9^{\mathrm{a}}$ & $30.0^{\mathrm{a}}$ & 0.124 & 0.00 \\
\hline C18:0 & 13.4 & 13.5 & 13.5 & 13.4 & 13.3 & 0.060 & 0.08 \\
\hline C16:1, n-9 & $2.71^{\mathrm{ab}}$ & $2.79^{\mathrm{a}}$ & $2.76^{a}$ & $2.66^{\mathrm{b}}$ & $2.68^{\mathrm{b}}$ & 0.030 & 0.04 \\
\hline C18:1, n-9 & 32.8 & 32.8 & 32.4 & 32.5 & 32.6 & 0.220 & 0.42 \\
\hline C20:1 & $0.56^{\mathrm{ab}}$ & $0.59^{\mathrm{a}}$ & $0.60^{\mathrm{a}}$ & $0.48^{c}$ & $0.49^{\mathrm{bc}}$ & 0.018 & 0.00 \\
\hline C18:2, n-6 & $14.8^{\mathrm{b}}$ & $14.6^{\mathrm{b}}$ & $14.9^{\mathrm{ab}}$ & $14.8^{\mathrm{b}}$ & $15.0^{\mathrm{a}}$ & 0.059 & 0.00 \\
\hline C18:3, n-3 & $1.41^{\mathrm{b}}$ & $1.45^{\mathrm{a}}$ & $1.45^{\mathrm{a}}$ & $1.46^{\mathrm{a}}$ & $1.47^{\mathrm{a}}$ & 0.007 & 0.00 \\
\hline C20:4, n-6 & $0.16^{b}$ & $0.15^{\mathrm{b}}$ & $0.16^{b}$ & $0.18^{\mathrm{a}}$ & $0.18^{\mathrm{a}}$ & 0.002 & 0.00 \\
\hline C20:5, n-3 EPA & 0.37 & 0.37 & 0.37 & 0.38 & 0.37 & 0.062 & 0.01 \\
\hline $\mathrm{C} 20: 2, \mathrm{n}-6$ & $0.51^{\mathrm{b}}$ & $0.51^{\mathrm{b}}$ & $0.52^{\mathrm{ab}}$ & $0.53^{\mathrm{a}}$ & $0.54^{\mathrm{a}}$ & 0.006 & 0.04 \\
\hline C22:5, n-3 DPA & $0.42^{c}$ & $0.47^{\mathrm{a}}$ & $0.46^{b}$ & $0.47^{\mathrm{a}}$ & $0.47^{\mathrm{a}}$ & 0.004 & 0.00 \\
\hline C22:6, n-3 DHA & $1.22^{\mathrm{b}}$ & $1.32^{\mathrm{a}}$ & $1.31^{\mathrm{a}}$ & $1.33^{\mathrm{a}}$ & $1.33^{\mathrm{a}}$ & 0.005 & 0.00 \\
\hline$S F A^{\star \star}$ & $44.4^{\mathrm{b}}$ & $44.2^{\mathrm{b}}$ & $45.1^{\mathrm{a}}$ & $45.1^{\mathrm{a}}$ & $45.1^{\mathrm{a}}$ & 0.110 & 0.00 \\
\hline MUFA ${ }^{\star \star}$ & 36.1 & 36.2 & 35.7 & 35.6 & 35.8 & 0.230 & 0.16 \\
\hline PUFA ${ }^{\star \star}$ & $18.9^{b}$ & $18.9^{\mathrm{b}}$ & $19.1^{\mathrm{ab}}$ & $19.1^{\mathrm{ab}}$ & $19.4^{\mathrm{a}}$ & 0.063 & 0.00 \\
\hline
\end{tabular}

*TPHO: 100\% crude protein (CP) from fishmeal (FM); TPH25: 75\% CP from FM and 25\% CP from Tra catfish by-product protein hydrolysate (TPH); TPH50: 50\% CP from FM and 50\% CP from TPH; TPH75: 25\% CP from FM and 75\% CP from TPH; TPH100: $100 \%$ CP from TPH.

**SFA: saturated fatty acids; MUFA: mono-unsaturated fatty acids; PUFA: poly-unsaturated fatty acids.

${ }^{\mathrm{a}, \mathrm{b}, \mathrm{c}}$ Means within row without a common superscript are significantly different $(P<0.05)$.

All diets in this research were formulated to contain similar CP and ME to avoid the effects of different levels of nitrogen and energy. The inclusion of TPH in the diets did not affect the ADFI, but the ADGs of pigs fed TPH100 were higher than in TPHO. This is probably because the TPH was produced with controlled proteolytic enzyme digestion, which hydrolyzed the protein into peptides and free amino acids (Folador et al., 2006). Furthermore, TPH is a high-quality animal protein source that provides an adequate supply of essential amino acids and fatty acids. In fact, results from this study indicated an increase in ADG for pigs on the TPH100 diet compared with those on TPH0. The increasing level of TPH replacement resulted in increased ADG and improved FCR. Minh (2014) found that TPH could be used to improve or modify physicochemical and functional properties such as solubility, fat absorption or sensory properties of proteins without losing its nutritional value. Theoretically, TPH consists mainly of low molecular weight peptides, which can be absorbed rapidly and improve growth performance of pigs (Wu, 1998). Hevroy et al. (2005) revealed that fish TPH is a good and easily digestible protein supplement, which agrees with results from this study. Furthermore, Gilbert et al. (2008) reported that the positive effects of fish TPH on animal performance might be because of the high content of short peptides and free amino acids, which are palatable and more readily absorbed than intact protein without preceding digestion by pancreatic proteases. In addition, enzymatic hydrolysis of proteins can be performed using endogenous enzymes (proteases existing in fish) or 
exogenous enzymes to promote the hydrolytic process, these enzymes strongly influence the molecular size and hydrophobicity of the hydrolysate (Batista et al., 2010). During the hydrolytic process, proteins are processed to small polypeptide chains or broken down into short chains of amino acids, thus increasing the protein availability and subsequent digestibility.

In the present study, the supplementation of TPH did not affect hot carcass and dressing percentage, but backfat thickness and EE contents in LD muscle increased with higher TPH inclusion in the diets. This is probably because the TPH was produced from catfish by-product, that is, high fat content by-product, which is a characteristic of the catfish product in the Mekong Delta of Vietnam (Thuy et al., 2011). This is in agreement with the study of Stahly \& Cromwell (1979), who showed that dietary fat supplementation increased the carcass backfat thickness in pigs raised at high ambient temperatures. However, chemical analysis of LD indicated no differences in moisture, CP and ash among diets, but the meat from pigs fed TPH100 and TPH75 had higher $\mathrm{L}^{*}$ (lightness) and $\mathrm{a}^{*}$ (redness) values than those given TPHO. The cause could probably be linked to the higher concentration of saturated fatty acids, especially C16:0 in the LD muscle fat, which makes the lipid less translucent and therefore brightens the colour of the pork (Teye et al., 2006). Theoretically, fat and fatty acids are important because of their effects on human health, and fatty acid composition is a major factor in the nutritional value of meat. Pigs are unable to synthesize essential fatty acids such as linoleic and linolenic acid, and they must be supplied in the diet. The fatty acid composition of pig meat is controlled mostly by diet (Kristinsson et al., 2001). In this study, the fat in TPH was mainly from catfish oil, which is a rich source of essential PUFAs, that is, the omega- 3 and omega- 6 families. Ho \& Paul (2009) showed that the high absolute contents of DHA (C22:6, n-3) and EPA (C20:5, n-3) in Tra Catfish makes it a potentially valuable source of omega-3 fatty acids. Thus, the higher the inclusion rate of TPH in the diet, the higher the DHA, EPA, DPA and other PUFAs in LD muscle. This is in agreement with Hallenstvedt et al. (2010), who showed that feeding fish oil to pigs did not affect the sensory quality of the loin, but increased the level of DHA, EPA and DPA in muscle.

The feed costs per kg live weight gain were 10\% lower in TPH100, compared with TPH0. Thus, 100\% replacement of FM by Tra Catfish by-product TPH reduced feed costs per $\mathrm{kg}$ gain to around $90 \%$ of the 100\% FM diet.

\section{Conclusions}

Replacing FM with Tra Catfish by-product TPH improved the performance and meat quality of growing-finishing pigs, but resulted in an increase in backfat thickness and EE contents in the LD muscle. However, because of the reduced feed costs, complete replacement of FM would still be profitable for pig producers in the Mekong Delta of Viet Nam.

\section{Acknowledgments}

The authors wish to thank the National Foundation for Science and Technology Development (Nafosted) of Viet Nam for the financial support of this study (Grant code number: 106-NN.05- 2013.68). Sincere gratitude goes to Experimental farm of Vemedim Animal Health Company in O Mon District, Can Tho City for carrying out the experiment.

\section{Authors' Contributions}

N.T.T. and N.C.H. were in charge of the experimental design and implementation. N.T.T. and M.J. wrote the manuscript. All authors participated in collating the results, carrying out statistical analyses, interpreting the study and correcting the manuscript.

\section{Conflict of Interest Declaration}

We wish to confirm that there are no conflicts of interest associated with the publication of this manuscript, and also confirm that this manuscript has been read and approved by all authors.

\section{References}

AOAC, 2000. Official Methods of Analysis (17th ed.). Association of Official Analytical Chemists, Inc. Arlington, Virginia, USA.

Batista, I., Ramos, C., Coutinho, J., Bandarra, N.M. \& Nunes, M.L., 2010. Characterization of protein hydrolysates and lipids obtained from black scabbard fish (Aphanopus carbo) by-products and antioxidative activity of the hydrolysates produced. Process Biochem. 45, 18-24.

Folador, J.F., Karr-Lilienthal, L.K., Parsons, C.M., Bauer, L.L., Utterback, P.L., Schasteen, C.S., Bechtel, P.J. \& Fahey Jr., G.C., 2006. Fish meal, fish components, and fish protein hydrolysates as potential ingredients in pet foods. J. Anim. Sci. 84, 2752-2765.

Folch, J., Lees, M. \& Sloane Stanley, G.H., 1957. A simple method for the isolation and purification of total lipids from animal tissues. J. Biol. Chem. 226, 497-509.

Gilbert, E.R., Wong, E.A. \& Webb Jr., K.E., 2008. Board-invited review: peptide absorption and utilization: implications for animal nutrition and health. J. Anim. Sci. 86, 2135-2155. 
GSO, 2014. General Statistics Office of Vietnam, Hanoi, Vietnam. http://www.gso.gov.vn

Hallenstvedt, E., Kjos, N.P., Rehnberg, A.C., Øverland, M. \& Thomassen, M., 2010. Fish oil in feeds for entire male and female pigs: changes in muscle fatty acid composition and stability of sensory quality. Meat Sci. 85, 182-190.

Hevrøy, E.M., Espe, M., Waagbø, R., Sandnes, K., Ruud, M. \& Hemre, G.I., 2005.Nutrient utilization in Atlantic salmon (Salmo salar $\mathrm{L}$ ) fed increased levels of fish protein hydrolysate during a period of fast growth. Aquacult. Nutr. 11, 301-313.

Ho, B.T. \& Paul, D.R., 2009. Fatty acid profile of Tra catfish (Pangasius hypophthalmus) compared to Atlantic salmon (Salmo solar) and Asian Seabass (Lates calcarifer). Int. Food Res. J. 16 (4), 501-506.

Kang-Lyung Woo, 2001. Amino acid analysis protocols. Humana Press, Totowa, New Jersey, 141-167.

Kenichi, I. \& Yumeto, F., 2010. Preparation of fatty acid methyl esters for gas-liquid chromatography. J. Lipid Res. 51, $635-640$

Kristinsson, H.G., Baldursdottir, B., Jonsdottir, R., Valdimarsdottir, T. \& Thorkelsson, G., 2001. Influence of feed fat source on fatty acid composition, unsaturation and lipid oxidation of backfat and sensory quality of pork. J. Muscle Foods. 12 (4), 285-300.

Minh, N.P., 2014. Utilization of Pangasius hypophthalmus by-product to produce protein hydrolysate using alcalase enzyme. J. Harmoniz. Res. Appl. Sci. 2 (3), 250-256.

Stahly, T.S. \& Cromwell, G.L.,1979. Effect of environmental temperature and dietary fat supplementation on the performance and carcass characteristics of growing and finishing swine. J. Anim. Sci. 49, 1478-1488.

Teye, G.A., Sheard, P.R., Whittington, F.M., Nute, G.R., Stewart, A. \& Wood, J.D., 2006. Influence of dietary oils and protein level on pork quality. 1. Effects on muscle fatty acid composition, carcass, meat and eating quality. Meat Sci. 73, 157-165.

Thuy, N.T., Lindberg, J.E. \& Ogle, B., 2011. Effects of replacing fish meal with catfish (Pangasius hypophthalmus) processing waste water on the performance of growing pigs. Trop. Anim. Health Prod. 43, 425-430.

Thuy, N.T., Trong, T.V., Duy, L.N.Đ. \& Ha, N.C., 2015. The hydrolysis of protein from Tra Fish by-product protein using enzyme papain. J. Anim. Sci. Technol. (NIAS). 53, 77-87. (in Vietnamese, English abstract).

Wu, G., 1998. Intestinal mucosal amino acid catabolism. J. Nutr. 128, 1249-1252. 